\title{
E-cadherin Gene Promoter Hyper-methylation in Blood Samples from Breast
}

\author{
Cancer Cases
}

Sadia Ajaz ${ }^{1 \#}$, Sani-e-Zehra Zaidi ${ }^{1}$, Saleema Mehboob Ali $^{1}$, Aisha Siddiqa ${ }^{2}$, Muhammad Ali Memon $^{2}$

${ }^{1 .}$ Dr. Panjwani Center for Molecular Medicine and Drug Research (PCMD), International Center for Chemical and Biological Sciences (ICCBS), University of Karachi, Karachi, Pakistan.

2. Atomic Energy Medical Centre (AEMC), Jinnah Postgraduate Medical Centre (JPMC), Karachi, Pakistan.

${ }^{\#}$ Corresponding Author:

Sadia Ajaz, Ph. D. 
medRxiv preprint doi: https://doi.org/10.1101/2021.03.30.21254647; this version posted April 6, 2021. The copyright holder for this preprint

\begin{abstract}
In carcinomas, dissemination of cancer cells via blood or lymph circulation constitutes an early event. E-cadherin is a transmembrane calcium dependent adhesion protein. Cellular dedifferentiation and plasticity, underlying metastasis, is attributed to the loss of function of $E$ cadherin $(c d h l)$ gene. The loss of gene expression may arise from promoter hypermethylation, which has been reported in multiple cancers. In the present pilot project, sixty (60) blood samples were collected from the breast cancer patients at a tertiary care hospital in Karachi, Pakistan. DNA was isolated from the cells circulating in the peripheral blood of the participants. Promoter hypermethylation was investigated through sodium-bisulfite treatment of DNA followed by methylation-specific PCR. In $53.3 \%$ of the patients, E-cadherin gene promoter hypermethylation was observed. Promoter hypermethylation of E-cadherin has been reported in DNA isolated from the tissue specimen. However, to the best of our knowledge this is the first report of E-cadherin promoter hypermethylation in cells isolated from the peripheral blood of breast cancer patients from a geographically specific population. The results have important implications in tumour staging and selection of treatment regimens.
\end{abstract}

\title{
Introduction
}

E-cadherin is a trans-membrane calcium-dependent adhesion glycoprotein. The protein expression is mainly restricted to epithelial cells (Bruner and Derksen, 2018). It is a critical protein at adherens junction, where it connects the epithelial cells to each other (Halbleib and Nelson, 2006). E-cadherin is a tumour suppressor (Berx, 1995; Guilford 1998; Perl 1998; and Derksen 2006). In cancers, the cadherins are frequently non-functional through gene inactivation 
medRxiv preprint doi: https://doi.org/10.1101/2021.03.30.21254647; this version posted April 6, 2021. The copyright holder for this preprint (which was not certified by peer review) is the author/funder, who has granted medRxiv a license to display the preprint in perpetuity.

All rights reserved. No reuse allowed without permission.

and/or functional inhibition. Consequently, these play siginficant role in tumourigenesis and progression (Wong, 2017). E-cadherin is considered to be clinically causal in carcinomas, particularly breast and gastric cancers (Derksen, 2006).

The encoding gene for E-cadherin $(C D H 1)$ is mapped to chromosome $16 \mathrm{q} 22.1$. A recent CRISPR/Cas9 experiment demonstrated tumour development and progression of breast carcinoma sub-type when dual incativation of $C D H 1$ and PTEN genes was carried out, (Annunziato, 2016). Clinically, inactivating germ-line and somatic mutations as well as $C D H 1$ promoter hypermethylation have been shown in breast cancers (Berx, 1995, 1996; Masciari, 2007; Strathdee, 2002). The epigenetic silencing of $C D H 1$ has also been reported in some human breast cancer cell lines (Yang, 2001; Szyf, 2004). However, in case of primary breast cancers, information regarding aberrant DNA methylation is limited. The current data shows frequency variation ranging from $21 \%$ to $80 \%$ (Cardeira, 2006; Liu, 2016), depending upon tumour subtype and stage. In the present study, we report the promoter hypermethylation analysis for epigenetic silencing of $C D H 1$ gene in the circulting cells, which were collected from peripheral blood samples of breast cancer patients.

\section{Methodology}

\section{Patients:}

A total of 67, with 60 eligible, blood samples were collected from the breast cancer patients at the Atomic Energy Medical Centre (AEMC), Jinnah Postgraduate Medical Centre (JPMC), Karachi, Pakistan were collected between July 2016 and July 2018. The blood samples were collected in ACD coated vacutainers (BD Vacutainer ${ }^{\circledR}$ BD Franklin Lakes NJ USA) and either processed immediately or stored at $4^{\circ} \mathrm{C}$. The study was approved by the ethical review committees (ERCs) of the participating institutions: the independent ERC, International Center 
medRxiv preprint doi: https://doi.org/10.1101/2021.03.30.21254647; this version posted April 6, 2021. The copyright holder for this preprint (which was not certified by peer review) is the author/funder, who has granted medRxiv a license to display the preprint in perpetuity.

All rights reserved. No reuse allowed without permission.

for Chemical and Biological Sciences (ICCBS), University of Karachi, Karachi, Pakistan

[ICCBS/IEC-016-BS/HT-2016/Protocol/1.0], and the Atomic Energy Medical Centre (AEMC),

Jinnah Postgraduate Medical Centre (JPMC), Karachi, Pakistan [Admin-3(257)/2016]. The

inclusion criteria for patients was diagnosis of primary breast cancer.

\subsubsection{Tumour Information}

The information regarding cancer including histological classification, tumour size, tumour grade, tumour stage, lymph node metastasis, and status of estrogen receptor (ER), progestrone receptor (PR), and human epidermal growth factor receptor-2 (HER-2) were obtained from the patients' medical records, where available. The patients were interviewed for age, family history of cancer, gynae and obs history, and ethnicity. The patients' information was documented in the form of a questionnaire.

\subsubsection{Bi-sulfite Treatment of DNA Samples}

DNA samples were treated with sodium bisulfite following standard protocol (Herman et al., 1996) with slight adjustments. $1 \mu \mathrm{g}$ of DNA sample (total volume adjusted to $45 \mu 1$ with autoclaved deionized water) was taken in $1.5 \mathrm{ml}$ microcentrifuged tube. For alkaline denaturation, $5.7 \mu \mathrm{l}$ of $3 \mathrm{M} \mathrm{NaOH}$ was added to each DNA samples. Samples were then incubated for 17 minutes in shaking waterbath at $37^{\circ} \mathrm{C}, 50 \mathrm{RPM}$. After incubation, unmethylated cytosine were converted to uracil by adding $530 \mu \mathrm{l}$ of freshly prepared mixture of $16 \mathrm{mM}$ hydroquinone and $4 \mathrm{M}$ liquid sodium bisulfite solution ( $\mathrm{pH}$ adjusted to 5 with $1 \mathrm{M} \mathrm{NaOH}$ solution) to each DNA samples. A drop of mineral oil was added to each sample. Samples were incubated for 16-18 hours, in shaking waterbath. 
medRxiv preprint doi: https://doi.org/10.1101/2021.03.30.21254647; this version posted April 6, 2021. The copyright holder for this preprint (which was not certified by peer review) is the author/funder, who has granted medRxiv a license to display the preprint in perpetuity.

All rights reserved. No reuse allowed without permission.

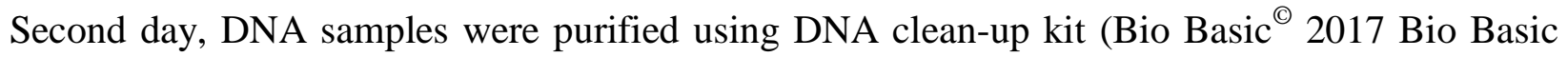
Inc., UK) following the instructions. To each purified DNA, 5.7 $\mu 1$ of $3 \mathrm{M} \mathrm{NaOH}$ was added, followed by incubation at $37^{\circ} \mathrm{C}$ for 17 minutes. After incubation, DNA was preciptated with $10 \mathrm{M}$ ammonium acetate $(17 \mu 1)$ and ice-cold absolute ethanol $(500 \mu 1)$. Samples were kept at $20^{\circ} \mathrm{C}$ for precepitation.

The next day, samples were centrifuged at maximam speed $(21,000 \mathrm{rcf})$ for 21 minutes at $4^{\circ} \mathrm{C}$.

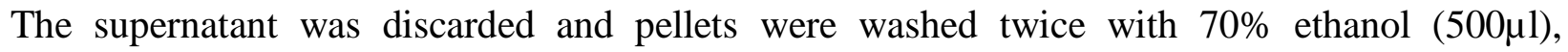
followed by centrifugation at maximam speed for 21 minutes. Supernatant was discarded and tubes were air dried at room temperture. DNA samples were then resuspended in $35 \mu 1$ of autoclaved deioninzed water. The samples were incubated in shaking waterbath at $37^{\circ} \mathrm{C}$ for 10 minutes for resuspension. DNA samples were then kept at $4^{\circ} \mathrm{C}$ till PCR.

\subsubsection{Methylation Specific Polymerase Chain Reaction (MS-PCR)}

Primer sequences for methylated and unmethylated PCR are listed in Table 1.

\begin{tabular}{lllllll}
\hline S.no & Gene & Forward primer & Reverse primer & Annealing & Product & Reference \\
& & $\mathbf{5} \square$ to $3 \square$ & $\mathbf{5} \square$ to $3 \square$ & $\begin{array}{l}\text { Temperature } \\
\text { size }\end{array}$ & \\
& & & $\left({ }^{\circ} \mathbf{C}\right)$ & (bp) & \\
\hline 1. & & & & 97 & \\
& & & & & & Herman, \\
& UnMetherin & TAATTTTAGGT & CACAACCAAT & 54 & Graff,
\end{tabular}




$\begin{array}{llllll}\text { 2. } & \text { E-cadherin } & \text { TTAGGTTAGA } & \text { TAACTAAAAA } 53.5 & 116 & \text { Myöhänen } \\ \text { Methylated } & \text { GGGTTATCGC } & \text { TTCACCTACC } & & \text {, Nelkin, } \\ & \text { GT } & \text { GAC } & & \text { and Baylin }\end{array}$

PCR reactions for methylated and unmethylated genes were carried out separately.

For unmethylated PCR, reaction was carried out in a total volume of $25 \mu 1$ containing $1 \mathrm{X}$ PCR, 4.5mM MgCl $2,1.5 \mathrm{mM}$ dNTPs, $1.9 \mu \mathrm{M} / \mu 1$ of primers, $3 \%$ DMSO, and 120ng of DNA.

Hot-start PCR was carried out. The samples were placed at $95^{\circ} \mathrm{C}$ for 5 minutes before the addition of $1.5 \mathrm{U} / \mu 1$ Taq polymerase (Thermofisher scientific.Inc., USA). Amplification was carried out using Kyratec SC300 super cycler. PCR conditions were: initial denaturation at $95^{\circ} \mathrm{C}$ for 5 minutes followed by 35 cycles of $95^{\circ} \mathrm{C}$ for 30 seconds, $54^{\circ} \mathrm{C}$ for 30 seconds, $72^{\circ} \mathrm{C}$ for 30 seconds. Final extension was carried out at $72^{\circ} \mathrm{C}$ for 10 minutes (Herman et al., 1996).

For methylated PCR, PCR mix of $25 \mu 1$ comprised $1 \mathrm{X}$ PCR buffer, $6.7 \mathrm{mM} \mathrm{MgCl}_{2} 1.5 \mathrm{mM}$ dNTPs, $1.85 \mu \mathrm{M} / \mu \mathrm{l}$ of each primer, $10 \mathrm{mM} \beta$-mercaptoethanol, $2 \mathrm{U} / \mu 1$ Taq polymerase and $120 \mathrm{ng}$ of DNA. Cycling conditions were similar to unmethylated PCR. Anealing tempertaure was $53.5^{\circ} \mathrm{C}$.

\section{Results}

The clinico-pathological features of the patients' samples included in the study are listed in Table 2 . 
Table-2 Clinicopathological characteristics of breast cancers cohort

\begin{tabular}{|c|c|c|}
\hline \multicolumn{2}{|r|}{ Parameter } & $\mathrm{N}$ or value $\%$ \\
\hline 1 & \multicolumn{2}{|c|}{$\operatorname{Age}\left(n^{*}=63\right)$} \\
\hline $1 \mathrm{a}$ & $\leq 40$ & $26(41.3 \%)$ \\
\hline $1 \mathrm{~b}$ & $>40$ & $37(58.7 \%)$ \\
\hline 2 & \multicolumn{2}{|c|}{ Tumor Site $(n *=63)$} \\
\hline $2 a$ & Right & $27(42.2 \%)$ \\
\hline $2 b$ & Left & $35(54.7 \%)$ \\
\hline $2 c$ & Bilateral & $01(1.60 \%)$ \\
\hline 3 & \multicolumn{2}{|c|}{ Molecular Sub-type $\left(\mathrm{n}^{*}=35\right)$} \\
\hline $3 a$ & Luminal A & $17(48.6 \%)$ \\
\hline $3 b$ & Luminal B & $05(14.3 \%)$ \\
\hline $3 c$ & Her $2 /$ neu & $04(11.4 \%)$ \\
\hline $3 d$ & Basal like & $09(25.7 \%)$ \\
\hline 4 & \multicolumn{2}{|c|}{ Histological Sub-type $(n *=63)$} \\
\hline $4 a$ & IDC & $54(85.7 \%)$ \\
\hline $4 \mathrm{~b}$ & DCIS & $01(1.6 \%)$ \\
\hline $4 e$ & IDC + DCIS & $05(7.9 \%)$ \\
\hline $4 f$ & Others & $03(4.7 \%)$ \\
\hline 5 & \multicolumn{2}{|c|}{ Receptor Status $(n *=49$ for ER \& PR; $n *=37$ for Her2-neu) } \\
\hline $5 a$ & ER positive & $31(63.2 \%)$ \\
\hline $5 b$ & ER negative & $18(36.7 \%)$ \\
\hline $5 d$ & PR positive & $30(61.2 \%)$ \\
\hline $5 e$ & PR negative & $19(38.8 \%)$ \\
\hline $5 g$ & Her2-neu positive & $10(27 \%)$ \\
\hline $5 \mathrm{~h}$ & Her2-neu negative & $27(73 \%)$ \\
\hline 6 & \multicolumn{2}{|c|}{ Tumor Size $\left(n^{*}=58\right)$} \\
\hline $6 a$ & $\mathrm{~T} 1(<2 \mathrm{~cm})$ & $09(15.5 \%)$ \\
\hline $6 b$ & $\mathrm{~T} 2(2-5 \mathrm{~cm})$ & $37(63.8 \%)$ \\
\hline $6 c$ & $\mathrm{~T} 3(>5 \mathrm{~cm})$ & $12(20.7 \%)$ \\
\hline 7 & \multicolumn{2}{|c|}{ Stage $(n *=43)$} \\
\hline
\end{tabular}


medRxiv preprint doi: https://doi.org/10.1101/2021.03.30.21254647; this version posted April 6, 2021. The copyright holder for this preprint (which was not certified by peer review) is the author/funder, who has granted medRxiv a license to display the preprint in perpetuity. All rights reserved. No reuse allowed without permission.

\begin{tabular}{|c|c|c|}
\hline $7 \mathrm{a}$ & Low (I-II) & $21(48.8 \%)$ \\
\hline $7 \mathrm{~b}$ & High (III-IV) & $22(51.2 \%)$ \\
\hline
\end{tabular}

" $n *$ ": number of samples with available data

Representative gels for $\mathrm{CDH} 1$ methylation and un-methylation are shown in figures 1 and 2, respectively 
medRxiv preprint doi: https://doi.org/10.1101/2021.03.30.21254647; this version posted April 6, 2021. The copyright holder for this preprint (which was not certified by peer review) is the author/funder, who has granted medRxiv a license to display the preprint in perpetuity.

All rights reserved. No reuse allowed without permission.

In the studied cohort of 60 breast cancer patients, E-cadherin hypermethylation was detected in $53.3 \%(32 / 60)$ of the cases. (Table 3$)$

$49 \%(18 / 36)$ of the cases are above 40 years while $58 \%(14 / 24)$ of the cases are below 40 years.

Table 3 Methylation status of selected breast cancer patients

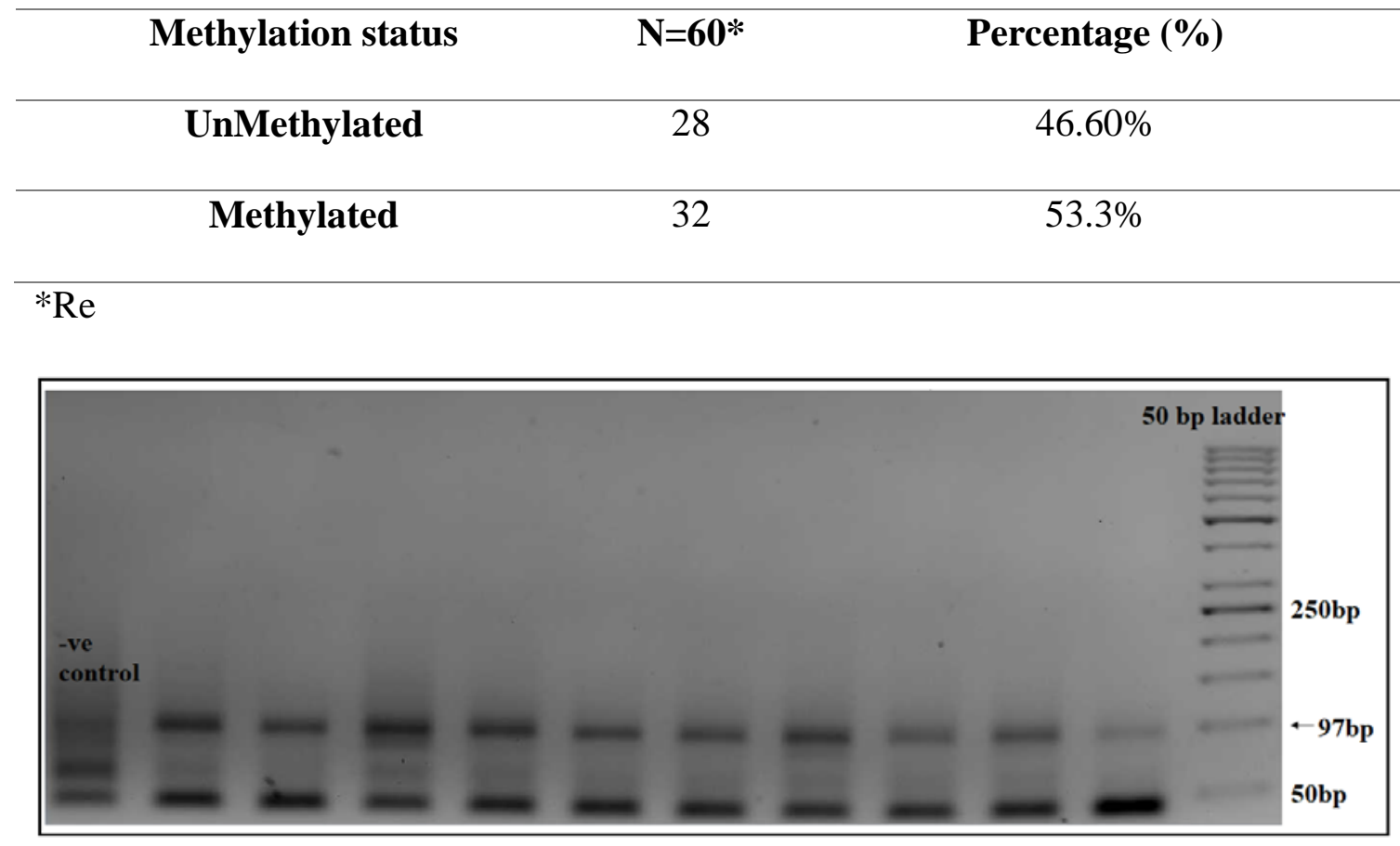

Figure 1 Agarose gel electrophoresis of MS-PCR product of UnMethylated E-cadherin promoter region, stained with ethidium bromide. Product size is 97bp. 
medRxiv preprint doi: https://doi.org/10.1101/2021.03.30.21254647; this version posted April 6, 2021. The copyright holder for this preprint (which was not certified by peer review) is the author/funder, who has granted medRxiv a license to display the preprint in perpetuity.

All rights reserved. No reuse allowed without permission.

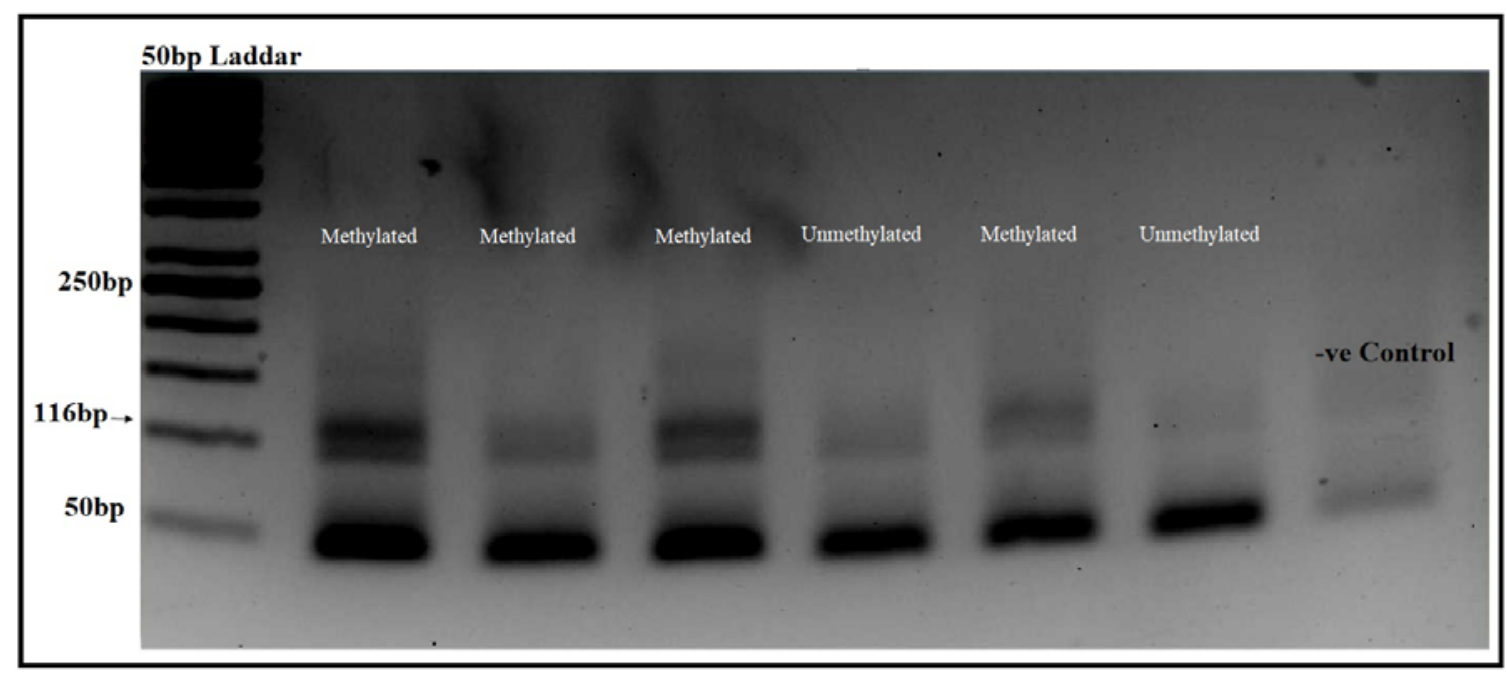

Figure 2 Agarose gel electrophoresis of MS-PCR product of methylated E-cadherin promoter region, stained with ethidium bromide. Product size is $116 \mathrm{bp}$.

\section{Discussion}

'Epigenetics' is combination of 'epigenesis' and 'genomic' which means 'on top or in addition to genetics'. The term was coined six decades ago based on mechanisms of cell fate commitment and lineage specification (Holliday, 1990; Waddington, 1959). Epigenetic changes can reversibly inactivate tumor suppressor gene in a heritable manner (Llinas-Arias and Esteller, 2017). These gene(s) are either packed into heterochromatin or hypermethylation of $\mathrm{CpG}$ island occurs. Such changes result in gene silencing that may attribute to tumor progression (Alberts, 2017).

E-cadherin being cell adhesion molecule, plays significant role in cancer metastasis. Reduced expression of E-cadherin is one of the molecular events in cancer progression (Nass et al., 2000). In the studied cohort, hypermethylation is correlated with breast cancers progression and metastasis.

In the studied cohort comprising both low and advanced stage breast cancer patients, $53.3 \%$ of the cases showed promoter hypermethylation of E-cadherin in DNA from circulating cells. To 
medRxiv preprint doi: https://doi.org/10.1101/2021.03.30.21254647; this version posted April 6, 2021. The copyright holder for this preprint (which was not certified by peer review) is the author/funder, who has granted medRxiv a license to display the preprint in perpetuity.

All rights reserved. No reuse allowed without permission.

the best of our knowledge this is the first report of E-cadherin promoter hypermethylation in cells isolated from the peripheral blood of breast cancer patients.

Two studies from Asia have analyzed $C D H 1$ promoter hyper-methylation in tissue samples from breast cancer patients. A study based on Kashmiri population has reported hypermethylation in $57.8 \%$ of the cases (Asiaf et al., 2014), whereas, another study from Iran reported hypermethylation in $94 \%$ of selected ductal-type breast cancer (Shargh et al., 2014).

In about $51 \%$ of IDC cases, E-cadherin hypermethylation was observed while in different studies, hypermethylation was observed in $30 \%$ of IDC cases (Nass et al., 2000).

\section{Conclusion}

The pilot study concludes that E-cadherin hypermethylation is involved in breast cancer progression in our population. Further investigation should be conducted to evaluate the role of E-cadherin in cancer metastasis and response to treatment.

This work was presented in a preliminary form in an MPhil thesis of one of the co-authors (SZZ).

\section{References:}

Alberts, B. (2017). Molecular Biology of The Cell: Garland science.

Asiaf, A., Ahmad, S. T., Aziz, S. A., Malik, A. A., Rasool, Z., Masood, A., and Zargar, M. A. (2014). Loss of expression and aberrant methylation of the CDH1 (E-cadherin) gene in breast cancer patients from Kashmir. Asian Pacific Journal of Cancer Prevention 15(15), 6397-6403. 
medRxiv preprint doi: https://doi.org/10.1101/2021.03.30.21254647; this version posted April 6, 2021. The copyright holder for this preprint (which was not certified by peer review) is the author/funder, who has granted medRxiv a license to display the preprint in perpetuity. All rights reserved. No reuse allowed without permission.

Herman, J. G., Graff, J. R., Myöhänen, S., Nelkin, B. D., and Baylin, S. B. (1996). Methylationspecific PCR: a novel PCR assay for methylation status of $\mathrm{CpG}$ islands. Proceedings of the National Academy of Sciences, 93(18), 9821-9826.

Kanherkar, R. R., Bhatia-Dey, N., and Csoka, A. B. (2014). Epigenetics across the human lifespan. Frontiers in Cell and Developmental Biology, 2(49). doi:10.3389/fcell.2014.00049

Ma, Y., Zhang, H., Xiong, C., Liu, Z., Xu, Q., Feng, J., ... Yan, X. (2018). CD146 mediates an E-cadherin-to-N-cadherin switch during TGF-beta signaling-induced epithelial-mesenchymal transition. Cancer Letter. doi:10.1016/j.canlet.2018.05.016

Mendonsa, A. M., Na, T. Y., and Gumbiner, B. M. (2018). E-cadherin in contact inhibition and cancer. Oncogene. doi:10.1038/s41388-018-0304-2

Mohammad, H. P., and Baylin, S. B. (2010). Linking cell signaling and the epigenetic machinery. Nature Biotechnology, 28, 1033. doi:10.1038/nbt1010-1033

Nass, S. J., Herman, J. G., Gabrielson, E., Iversen, P. W., Parl, F. F., Davidson, N. E., and Graff, J. R. (2000). Aberrant methylation of the estrogen receptor and E-cadherin 5' CpG islands increases with malignant progression in human breast cancer. Cancer Research, 60(16), 43464348.

Powan, P., Luanpitpong, S., He, X., Rojanasakul, Y., and Chanvorachote, P. (2017). Detachment-induced E-cadherin expression promotes 3D tumor spheroid formation but inhibits tumor formation and metastasis of lung cancer cells. American Journal of Physiology-Cell Physiology, 313(5), C556-C566. doi:10.1152/ajpcell.00096.2017 
medRxiv preprint doi: https://doi.org/10.1101/2021.03.30.21254647; this version posted April 6, 2021. The copyright holder for this preprint (which was not certified by peer review) is the author/funder, who has granted medRxiv a license to display the preprint in perpetuity. All rights reserved. No reuse allowed without permission.

Shargh, S. A., Sakizli, M., Khalaj, V., Movafagh, A., Yazdi, H., Hagigatjou, E., ... Khorram Khorshid, H. R. (2014). Downregulation of E-cadherin expression in breast cancer by promoter hypermethylation and its relation with progression and prognosis of tumor. Medical Oncology, 31(11), 250. doi:10.1007/s12032-014-0250-y 